\title{
Development of Manganese Master Alloy for Aluminum Alloys and the Technology of Its Application
}

\author{
Ainur Minnegayanovich Valiev ${ }^{1}$, Lenar Rustamovich Kharisov ${ }^{2}$, Dmitry Leonidovich Pankratov ${ }^{3}$, \\ Radik Nurgayazovich Gatin ${ }^{4}$ \\ ${ }^{l}$ PhD in engineering, Associate Professor, Department of Mechanical Engineering, Naberezhnye Chelny Institute, \\ KFU, http://orcid.org/0000-0002-4758-6315 \\ ${ }^{2} \mathrm{PhD}$ in engineering, Associate Professor, Department of Mechanical Engineering, Naberezhnye Chelny Institute, \\ KFU, ORCID - https://orcid.org/0000-0003-0434-0718 \\ ${ }^{3}$ Doctor of Technical Sciences, Professor, Department of Mechanical Engineering, Naberezhnye Chelny Institute, \\ KFU, http://orcid.org/0000-0001-6628-2280 \\ Master's Degree Student, Department of Mechanical Engineering, Naberezhnye Chelny Institute, KFU,
}

\begin{abstract}
Currently, aluminum and its alloys are used in many areas of industry and technology. First of all, aluminum and its alloys are used by the aviation and automotive industries. Aluminum is widely used in other industries: mechanical engineering, electrical engineering and instrument making, industrial and civil construction, chemical industry, the production of consumer goods, and food industry. Aluminum firmly took first place among other non-ferrous metals in terms of production scale and economic importance. The latest developments in these and other industries will allow this metal to strengthen its leading position as a key structural material of the 21-st century. The production of quality products from aluminum alloys is impossible without adding alloying elements to the melt. The compositions and technologies for alloying element introduction are very diverse. This work is devoted to the development of a master alloy for aluminum melts with manganese and the technology of its application. To achieve this goal, the following tasks were solved: they performed the analysis of existing master alloys for aluminum melts with manganese and the technology of their application; they developed a highly effective alloy for aluminum with manganese melt; they developed the recommendations for the practical application of the proposed manganese-containing master alloy.
\end{abstract}

Keywords: manganese ligature, aluminum melt, powdery additive, pelleted additive, foundry.

\section{INTRODUCTION}

At present, it is of interest to develop a highly efficient master alloy for aluminum melts with manganese and technology for its application. At the first stage, the task was to determine the rational form of the ligature. They considered the variants of powdery and pelleted materials. As is known, aluminum forms a sufficiently strong, chemically dense and thermally resistant $\mathrm{Al}_{2} \mathrm{O}_{3}$ film. When they introduce any additives into the melt, there is a possibility that the introduced material will be insulated from the contact with the liquid metal by the film covering it. It seemed effective to introduce various salts with manganese that destroy the continuity of the $\mathrm{Al}_{2} \mathrm{O}_{3}$ film and prevent the dissolution of manganese. $\mathrm{KBF}_{4}$ was chosen as such a salt [1-3].

\section{METHODS}

To carry out experiments, weighed portions were introduced into the 6060 melt under the metal mirror at the temperature of $730{ }^{\circ} \mathrm{C}$, followed by intensive mixing of the melt during the entire control period of assimilation. Weighed portions with manganese were powdery and pelleted mixtures of $50 \% \mathrm{Mn}+$ $50 \% \mathrm{KBF}_{4}$. The amount of the added additive was $2 \%$ of the melt mass, which could give its increase in the metal by $1 \%$ with the complete assimilation of the introduced manganese. The samples for chemical analysis were taken before the introduction of the ligature and after a predetermined exposure with continuous stirring. The manganese content before the introduction of the ligature was taken to be zero for greater visualization of the result.

The resulting dependences are shown on Figure 1 and 2.

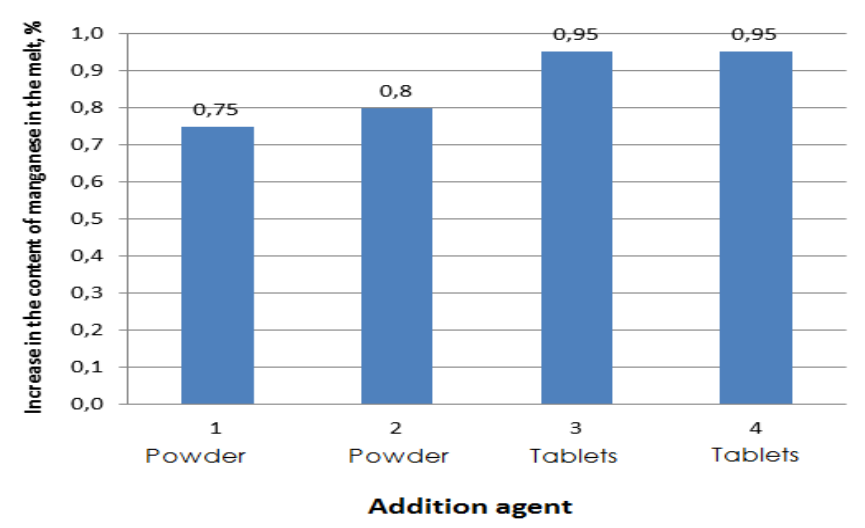

Figure 1: The dependence of the increase in the content of manganese in the melt after fifteen-minute mixing on the dispersion of manganese particles when entering it in the form of a powder and tablet mixture of the composition $50 \% \mathrm{Mn}+$ $50 \% \mathrm{KBF}_{4}$ 
1. Powdered additive $50 \% \mathrm{Mn}+50 \% \mathrm{KBF}_{4}$ with a manganese particle size of $0.1 \ldots 0.5 \mathrm{~mm}$.

2. Powdered additive $50 \% \mathrm{Mn}+50 \% \mathrm{KBF}_{4}$ with a manganese particle size of $1.0 \ldots 3.0 \mathrm{~mm}$.

3. Tableted additive $50 \% \mathrm{Mn}+50 \% \mathrm{KBF}_{4}$ with a manganese particle size of $0.1 \ldots 0.5 \mathrm{~mm}$.

4. Tableted additive $50 \% \mathrm{Mn}+50 \% \mathrm{KBF}_{4}$ with a manganese particle size of $1.0 \ldots 3.0 \mathrm{~mm}$.

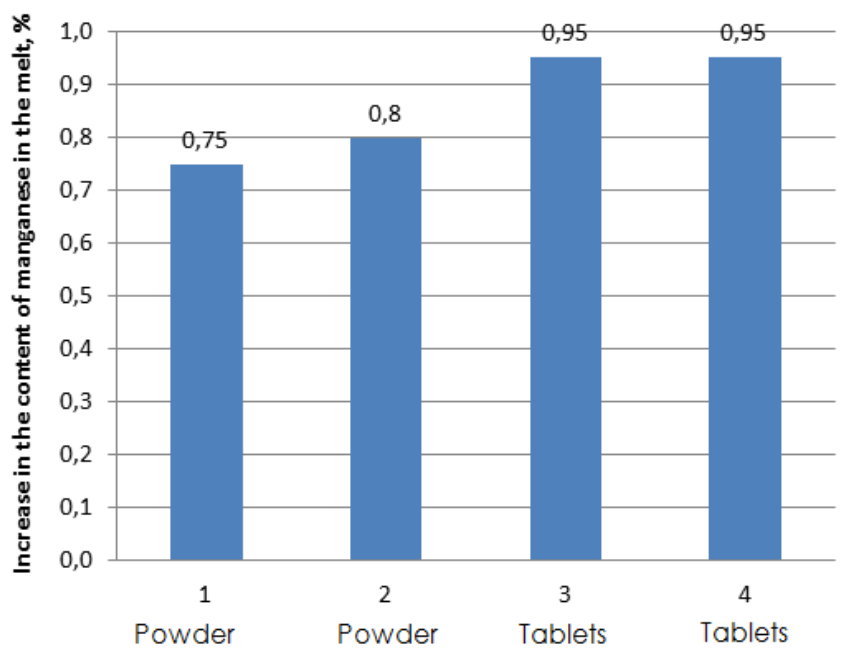

Addition agent

Figure 2: Dependence of the increase in the content of manganese in the melt after thirty-minute mixing on the dispersion of manganese particles when entering it in the form of a powder and tablet mixture of the composition $50 \% \mathrm{Mn}+$ $50 \% \mathrm{KBF}_{4}$

1. Powdered additive $50 \% \mathrm{Mn}+50 \% \mathrm{KBF}_{4}$ with a manganese particle size of $0.1 \ldots 0.5 \mathrm{~mm}$.

2. Powdered additive $50 \% \mathrm{Mn}+50 \% \mathrm{KBF}_{4}$ with a manganese particle size of $1.0 \ldots 3.0 \mathrm{~mm}$.

3. Tableted additive $50 \% \mathrm{Mn}+50 \% \mathrm{KBF}_{4}$ with a manganese particle size of $0.1 \ldots 0.5 \mathrm{~mm}$.

4. Tableted additive $50 \% \mathrm{Mn}+50 \% \mathrm{KBF}_{4}$ with a manganese particle size of $1.0 \ldots 3.0 \mathrm{~mm}$.

\section{RESULTS AND DISCUSSION}

It can be seen from the results that after intensive fifteenminute stirring of the melt, the increase of manganese content in the metal is not observed for the used manganese fractions, which indicates its fairly complete assimilation with a specific method of introduction.

It should be noted that the introduction of manganese into the aluminum melt in the form of a powder mixture with $\mathrm{KBF}_{4}$ provides less assimilation: for $0.1 \ldots 0.5 \mathrm{~mm}$ fraction $-0.75 \%$, for $1.0 \ldots 3.0 \mathrm{~mm}$ fraction $-0.8 \%$, in comparison with $0.95 \%$ increase of manganese melt when it is introduced in the form of tablets containing $50 \% \mathrm{Mn}+50 \% \mathrm{KBF}_{4}$ with manganese particle sizes of $0.1 \ldots 0.5 \mathrm{~mm}$ and $1.0 \ldots 3.0 \mathrm{~mm}$.

This result is probably associated with slagging and oxidation of manganese when it is introduced in the form of a powder mixture, since it is practically impossible to introduce the powder mixture effectively under the mirror of the melt, as is the case when they use sinking tablets [4].

The lower assimilation of manganese with a higher dispersion of its particles in the case of a powdery additive use is explained by the fact that the fine fraction is retained by the oxide film and slag phase on the melt surface to a greater extent, which leads to increased slagging and fumes of manganese in comparison with the larger size of manganese particles [5].

To exclude preliminarily the influence of the salt content in the master alloy being developed, they performed similar studies of powder and tableted compositions $90 \% \mathrm{Mn}+10 \%$ $\mathrm{KBF}_{4}$ with the dispersion of the following manganese particles: $0.1 \ldots 0.5 \mathrm{~mm}$ and $1.0 \quad \ldots \quad 3.0 \mathrm{~mm}$. The results are shown on Figure 3 and 4.

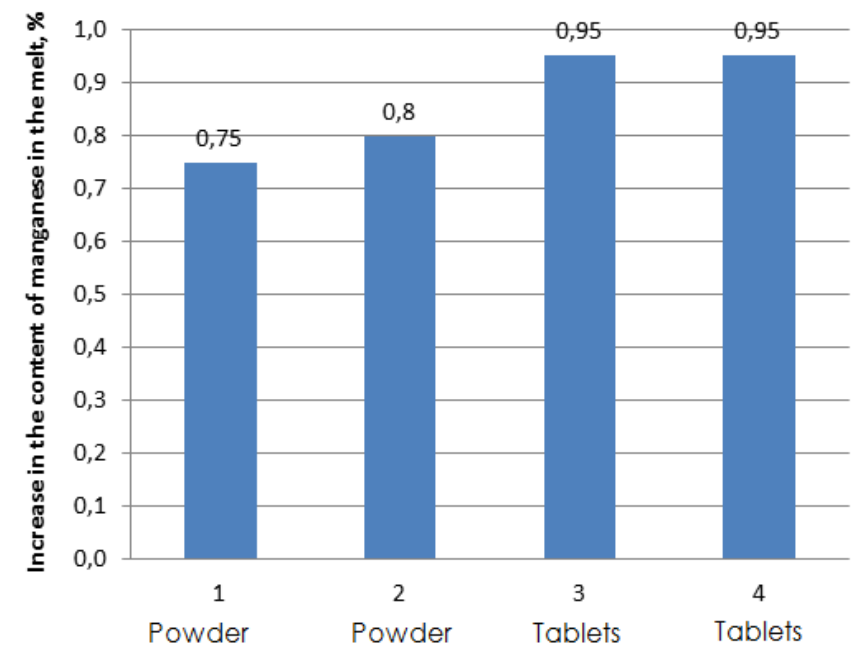

Addition agent

Figure 3: The dependence of the increase in the content of manganese in the melt after fifteen-minute mixing on the dispersion of manganese particles when entering it in the form of a powder and tablet mixture of the composition $90 \% \mathrm{Mn}+$ $10 \% \mathrm{KBF}_{4}$

1. Powdered additive $90 \% \mathrm{Mn}+10 \% \mathrm{KBF}_{4}$ with a manganese particle size of $0.1 \ldots 0.5 \mathrm{~mm}$.

2. Powdered additive $90 \% \mathrm{Mn}+10 \% \mathrm{KBF}_{4}$ with a manganese particle size of $1.0 \ldots 3.0 \mathrm{~mm}$.

3. Tableted additive $90 \% \mathrm{Mn}+10 \% \mathrm{KBF}_{4}$ with a manganese particle size of $0.1 \ldots 0.5 \mathrm{~mm}$.

4. Tableted additive $90 \% \mathrm{Mn}+10 \% \mathrm{KBF}_{4}$ with a manganese particle size of $1.0 \ldots 3.0 \mathrm{~mm}$. 


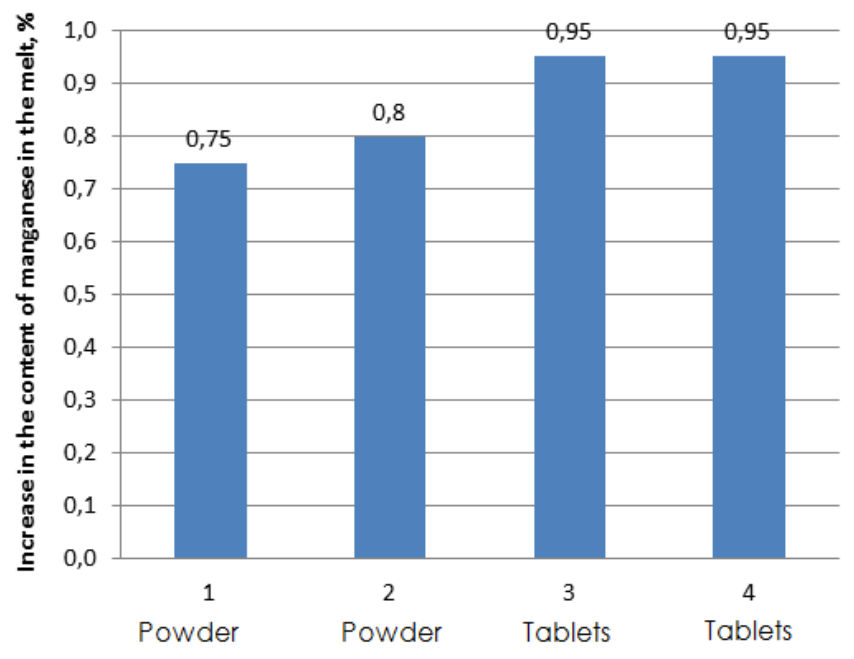

Addition agent

Figure 4: Dependence of the increase in the content of manganese in the melt after thirty-minute mixing on the dispersion of manganese particles when entering it in the form of a powder and tablet mixture of the composition $90 \% \mathrm{Mn}+$ $10 \% \mathrm{KBF}_{4}$

1. Powdered additive $90 \% \mathrm{Mn}+10 \% \mathrm{KBF}_{4}$ with a manganese particle size of $0.1 \ldots 0.5 \mathrm{~mm}$.

2. Powdered additive $90 \% \mathrm{Mn}+10 \% \mathrm{KBF}_{4}$ with a manganese particle size of $1.0 \ldots 3.0 \mathrm{~mm}$.

3. Tableted additive $90 \% \mathrm{Mn}+10 \% \mathrm{KBF}_{4}$ with a manganese particle size of $0.1 \ldots 0.5 \mathrm{~mm}$.

4. Tableted additive $90 \% \mathrm{Mn}+10 \% \mathrm{KBF}_{4}$ with a manganese particle size of $1.0 \ldots 3.0 \mathrm{~mm}$

Obviously, the amount of $\mathrm{KBF}_{4}$ salt $(50 \%$ or $10 \%)$ for the studied technological conditions (intensive mixing during the entire period of the specified assimilation time) does not affect the result, and the tableted alloying composition is more effective than the powder composition. Thus, further research was aimed at finding a rational composition of the tableted ligature and effective technological parameters of its use.

The next step was the selection of the salt included in the alloying additive. $\mathrm{KBF}_{4}, \mathrm{Na}_{3} \mathrm{AlF}_{6}, \mathrm{~K}_{2} \mathrm{TiF}_{6}, \mathrm{NaCl}, \mathrm{KCl}$ were considered as salts. The amount of salt in the ligature was chosen equal to $50 \%$ by weight, which is confirmed by previous studies (Fig. 1, 2).

Tableted materials of the following compositions were studied to search for salt:
1. Pure Mn,
2. $50 \% \mathrm{Mn}+50 \% \mathrm{KBF}_{4}$,
3. $50 \mathrm{Mn}+50 \% \mathrm{Na}_{3} \mathrm{AlF}_{6}$,
4. $50 \% \mathrm{Mn}+50 \% \mathrm{~K}_{2} \mathrm{TiF}_{6}$,

$$
\begin{aligned}
& \text { 5. } 50 \% \mathrm{Mn}+50 \% \mathrm{NaCl} \text {, } \\
& \text { 6. } 50 \% \mathrm{Mn}+50 \% \mathrm{KCl} .
\end{aligned}
$$

Tableted ligatures of the indicated compositions were introduced into 6060 melt at the temperature of $730{ }^{\circ} \mathrm{C}$, followed by intensive stirring of the melt during the entire fifteen-minute exposure. The size of manganese particles in all variants was $0.1 \ldots 0.5 \mathrm{~mm}$. The experimental results are shown on Figure 5.

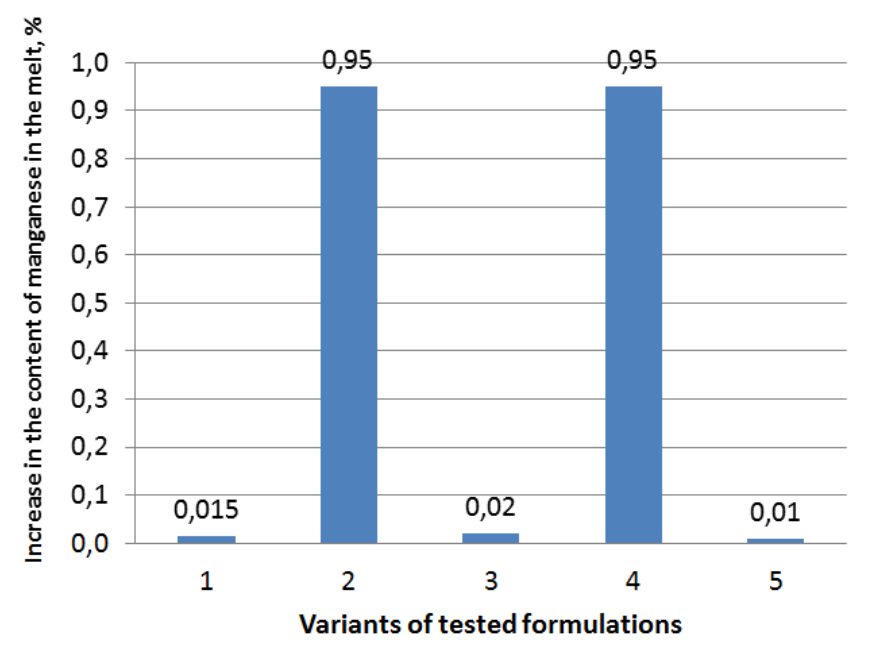

Figure 5: Increase in the content of manganese in the melt when processing it with tableted ligatures of various compositions

$$
\begin{array}{ll}
\text { 1. } & \text { Pure Mn, } \\
\text { 2. } & 50 \% \mathrm{Mn}+50 \% \mathrm{KBF}_{4}, \\
\text { 3. } & 50 \mathrm{Mn}+50 \% \mathrm{Na}_{3} \mathrm{AlF}_{6}, \\
\text { 4. } & 50 \% \mathrm{Mn}+50 \% \mathrm{~K}_{2} \mathrm{TiF}_{6}, \\
\text { 5. } & 50 \% \mathrm{Mn}+50 \% \mathrm{NaCl}, \\
\text { 6. } & 50 \% \mathrm{Mn}+50 \% \mathrm{KCl}
\end{array}
$$

The results obtained indicate that a salt with a low decomposition temperature must be used as a component of alloying tablets. This material destroys the pellet when heated, and this provides a large surface of "metal manganese - melt" interaction. It should also be noted that the tablets of the compositions 1,3,5,6 did not collapse and continued to lie without visible changes in the furnace bottom.

We choose $\mathrm{KBF}_{4}$ as a component for the ligature being created, as the cheapest and more accessible material in comparison with $\mathrm{K}_{2} \mathrm{TiF}_{6}$.

The next stage of research was the search for the optimal ratio of manganese - the ligature salt. For this, the metal was treated with a tableted master alloy of the following compositions with the following dispersion of the used manganese: $0.1 \ldots$ $0.5 \mathrm{~mm}$.

1. $50 \% \mathrm{Mn}+50 \% \mathrm{KBF}_{4}$, 
2. $60 \% \mathrm{Mn}+40 \% \mathrm{KBF}_{4}$,

3. $70 \% \mathrm{Mn}+30 \% \mathrm{KBF}_{4}$,

4. $80 \% \mathrm{Mn}+20 \% \mathrm{KBF}_{4}$,

5. $90 \% \mathrm{Mn}+10 \% \mathrm{KBF}_{4}$,

6. $100 \% \mathrm{Mn}+0 \% \mathrm{KBF}_{4}$.

To determine the rational composition of the tableted master alloy, we select the technological schedule for ten-minute intensive mixing of the AK5M2 melt at the temperature of $730{ }^{\circ} \mathrm{C}$. The choice of this regulation is due to practical consideration exclusively, which minimizes labor costs during mixing and relatively easy fit into most of the existing technologies of foundries and metallurgical shops.

The results of rational composition of the manganesecontaining master alloy determination are shown on Figure 6.

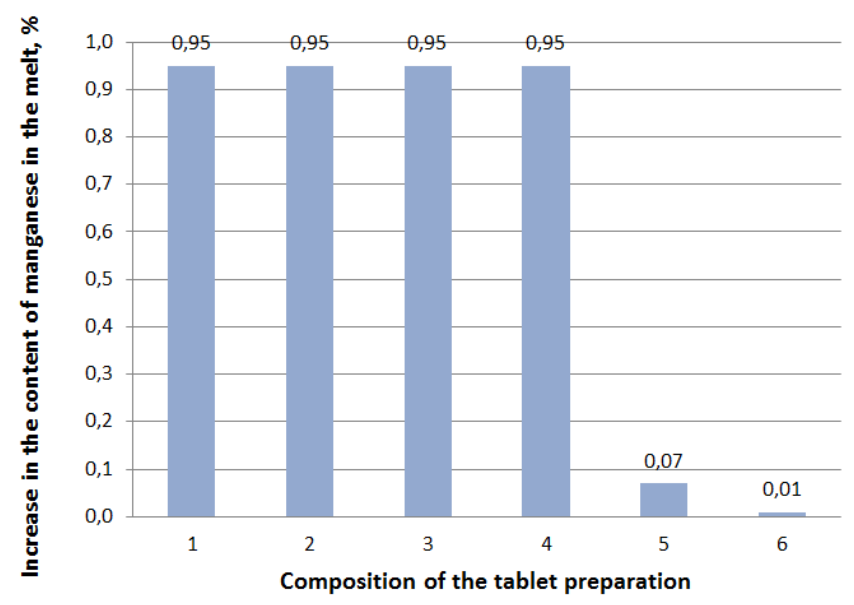

Figure 6: Increase in the content of manganese in the melt after processing manganese containing ligatures of various percentages followed by intensive ten minute mixing
1. $50 \% \mathrm{Mn}+50 \% \mathrm{KBF}_{4}$,
2. $60 \% \mathrm{Mn}+40 \% \mathrm{KBF}_{4}$,
3. $70 \% \mathrm{Mn}+30 \% \mathrm{KBF}_{4}$,
4. $80 \% \mathrm{Mn}+20 \% \mathrm{KBF}_{4}$,
5. $90 \% \mathrm{Mn}+10 \% \mathrm{KBF}_{4}$,
6. $100 \% \mathrm{Mn}+0 \% \mathrm{KBF}_{4}$,

The results obtained indicate that the most rational composition is the composition containing $80 \%$ of $\mathrm{Mn}+20 \%$ of $\mathrm{KBF}_{4}$. This composition makes it possible to minimize the content of the salt component in a tablet while maintaining a high degree of manganese assimilation $(0.95 \%)$ with intensive ten-minute stirring of the melt. This composition was used in further research.

The next step was the search for a rational degree of metallic manganese particle dispersion used for the preparation of the tableted master alloy. It is clear that with fineness increase to a certain level, the time of master alloy mastering will be decreased, however, crushing of metallic manganese is a laborious process and the use of larger fractions of manganese during the manufacture of tableted master alloy will reduce the cost of the latter $[6,7]$.

To determine the rational size of crushed metallic manganese particles used in the manufacture of tableted master alloy, the time dependence of manganese assimilation was studied with the following sizes of its particles: $0.1 \ldots 0.5 \mathrm{~mm}, 0.5 \ldots 1.0$ $\mathrm{mm}, 1.0 \ldots 3.0 \mathrm{~mm}, 3.0 \ldots 5.0 \mathrm{~mm}$.

The results of manganese particle rational size determination in the tableted master alloy are shown on Figure 7 (the amount of introduced material was determined based on the manganese content increase in the melt by $1 \%$, the composition of the tablets is $80 \%$ of $\mathrm{Mn}+20 \%$ of $\mathrm{KBF}_{4}$, the time of intensive mixing after the introduction of the master alloy is up to 16 minutes, the alloy $\mathrm{AK}_{5} \mathrm{M}_{2}$, the melt temperature was $730^{\circ} \mathrm{C}$ ) [8-10].

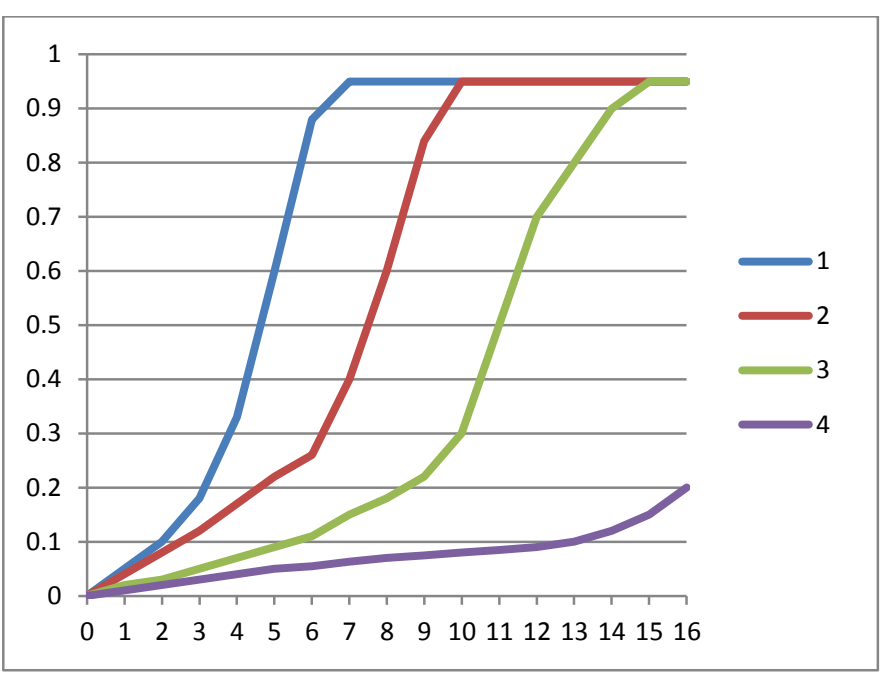

Figure 7: Dependence of the increase in the content of manganese in the melt on the size of the manganese particles in the tableted ligature

1. Particle size: $0,1 \ldots 0,5 \mathrm{~mm}$
2. Particle size: $0,5 \ldots 1,0 \mathrm{~mm}$
3. Particle size: $1,0 \ldots 3,0 \mathrm{~mm}$
4. $\quad$ Particle size: $3,0 \ldots 5,0 \mathrm{~mm}$

\section{CONCLUSIONS}

The results obtained allow us to conclude that compliance with the technological regulations (maximum assimilation of manganese with ten-minute stirring) provides alloying tablets with a manganese the particle size of $0.1 \ldots 0.5 \mathrm{~mm}$ and $0.5 \ldots$ $1.0 \mathrm{~mm}$. However, it should be taken into account that when the size of manganese particles is $0.5 \ldots 1.0 \mathrm{~mm}$, the required degree of manganese assimilation $(0.95 \%)$ is achieved by the 
tenth minute of intensive mixing. It is clear that a margin is needed to ensure the guaranteed receipt of the required result in any process and action. In this regard, the choice of crushed manganese use with a particle size of $0.5 \ldots 1.0 \mathrm{~mm}$ seems to be wrong. Thus, it is rational to use the particles of $0.1 \ldots 0.5$ $\mathrm{mm}$ when you determine the size of manganese particles in the tableted master alloy for aluminum alloys.

\section{SUMMARY}

After the studies carried out, a tableted ligature was developed for aluminum melts with manganese and rational parameters of its industrial use technology were determined.

\section{ACKNOWLEDGEMENTS}

The work is performed according to the Russian Government Program of Competitive Growth of Kazan Federal University.

\section{REFERENCES}

[1] Deep processing of melts with hightemperature media / V.L. Naydek, A.V. Narivsky, V.I. Sinichak, Yu.P. Lenda // Foundry. - 1992. - No. 9. - pp. 5-6.

[2] Methods, means, technologies, and materials for the production of complex high-quality castings from aluminum alloys / S.P. Zadrutsky, S.P. Korolev, B.M. Nemenenok, A.G. Sheshko, V.M. Mikhailovsky // Foundry worker of Russia. - 2005. - No. 6. - pp. 27-34.

[3] Verkhovsky Yu.T., Pivneva T.A. New modifiers for silumins // Raising the technical level and technological process improvement for the production of castings: Abstracts of reports from the 5th Rep. scientific and technical Conf. - Dnepropetrovsk, 1990. - pp. 58-59.

[4] Fedotov V.M. Influence of modification on AL9 alloy properties. // New materials and technologies: Abstracts of reports from Russ. scientific. tech. conf. - M.: 1994. - pp. 3-21.

[5] Modern materials for aluminum melt processing. / Zadrutskiy S.P., Nemenenok B.M., Korolev S.P. et al. - 2006 // Casting processes, No. 4. - pp. 9-14.

[6] Safronov N.N., Kharisov L.R., Safronov G.N. Strength of shs aluminium cast iron from dispersed mechanical engineering waste // Solid State Phenomena. Volume 284 SSP -
2018. - P.679-684. 4th International Conference on Industrial Engineering, ICIE 2018. DOI:

10.4028/www.scientific.net/SSP.284.679

[7] Malinovsky D.A., Safronov N.N., Kharisov L.R. Improvement of Gating Systems with the Purpose of Reducing Defects in Large-Size Castings from Gray Iron // HELIX. 2019. Volume: 9. Issue: 4. - pp. 5197-5203. DOI: 10.29042/2019-5197-5203

[8] Zagretdinov Z.T., Safronov N.N., Kharisov L.R. Getting Aluminum Bronze Castings with SHS-Cast // HELIX. 2019. - Volume: 9. Issue: 4. - pp. 5191-5196. DOI: 10.29042/2019-5191-5196

[9] Safronov G.N., Kharisov L.R., Safronov N.N. The Formation of Spherical Graphite in Cast Irons with the Economy of Rare Earth Metals// HELIX. 2019. Volume: 9. Issue: 4. - pp. 5175-5177. DOI: 10.29042/2019-5175-5177

[10] Kharisov L.R., Mingaleev A.M., Safronov N.N. Installation of Centrifugal Casting of Aluminum Cast Iron in the Process of SelfSpreading High-Temperature Synthesis // HELIX. 2019. - Volume: 9. Issue: 5. - pp. 5384-5389. DOI: 10.29042/2019-5384-5389 